\title{
Fra redaktionen
}

Udenrigs' tidligere redaktør og medlem af redaktionskomiteen, Vibeke Sperling, døde lørdag den 13. maj, og vi bringer på næste side en nekrolog.

Ellers er fokus i dette nummer først og fremmest på Afrika, verdens næststørste kontinent, der strækker sig $8.000 \mathrm{~km}$ fra nord til syd, og som rummer flere stater end noget andet kontinent. I fire artikler ser vi på det enorme kontinent fra forskellige vinkler, vel vidende at temaet kun kan blive en appetitvækker. Morten Jerven beskæftiger sig med fortællinger om den økonomiske udvikling i Afrika - og det som han betragter som økonomernes fejlvurderinger; Casper Andersen analyserer de koloniale grænsedragninger og konsekvenserne heraf for dagens Afrika; Ulrik Spliid giver en oversigt over Afrikas institutionelle landskab; og endelig ser Holger Bernt Hansen på et fænomen, der er udbredt i Afrika: langtidspræsidenterne.

Baggrundssektionen indledes med Sten Rynnings og Christilla Roederer-Rynnings status over præsident Donald Trumps første tid i Det Hvide Hus; derefter argumenterer Henning Sørensen for, at den politiske kontrol med det danske forsvar har nået et kritisk punkt, hvor den svækker forsvarets effektivitet; og endelig gennemgår Tysklands ambassadør i Danmark, Claus Robert Krumrei, nogle af de udfordringer, som Europa står overfor i en verden i forandring. Baggrundssektionen afsluttes med de tre vinderbidrag fra årets artikelkonkurrence, der udskrives i samarbejde med Udenrigsministeriet, og som i år havde temaet 'Internationale statslige organisationer i den ny verdensorden'.

I bogsektionen bringer vi hele seks anmeldelser. Ud over en anmeldelse af en Afrika-bog - Finn Rasmussens og Peter Tygesens Afrika - fortid og fremtid - spænder de anmeldte værker fra den gedigne Handbook of the Politics of the Arctic og Martin Marcussens store værk Diplomati. Et portreet af den moderne udenrigstjeneste over Samuel Rachlins Bag den kolde krigs tåger. Stalins arv til et splittet Europa og Rasmus Alenius' Efter Foråret - Forandringer i Arabisk Politik til hyldestskriftet til professor emeritus Frederik Harhoff Mod og mening. Til gengæld udkommer dette nummer desværre uden de bognoter, som Vibeke Sperling de seneste år har bestyret; men vi lover, at de vender tilbage i næste nummer.

God læselyst! 